\title{
Role of the Vps34p-interacting protein Ade5,7p in hyphal growth and virulence of Candida albicans
}

Correspondence

Raimund Eck

raimund.eck@fh-jena.de

Received 2 November 2006

Revised 1 March 2007

Accepted 5 March 2007

\author{
Susann Jezewski, ${ }^{1} \dagger$ Monika von der Heide, ${ }^{1}$ Sophia Poltermann, ${ }^{1}$ \\ Albert Härtl, ${ }^{1}$ Waldemar Künkel, ${ }^{2}$ Peter F. Zipfel ${ }^{1}$ and Raimund Eck $^{2} \ddagger$ \\ 'Leibniz Institute for Natural Products Research and Infection Biology/Hans Knöll Institute, \\ Beutenbergstrasse 11, D-07745 Jena, Germany \\ ${ }^{2}$ University of Applied Sciences, Carl-Zeiss-Promenade 2, D-07745 Jena, Germany
}

The phosphatidylinositol (Ptdlns) 3-kinase Vps34p of the human pathogenic yeast Candida albicans participates in virulence and in protein transport. In order to dissect these two functions, a search for proteins interacting with $C$. albicans Vps34p was performed using a yeast two-hybrid system. This study demonstrates the physical interaction between Vps34p and Ade5,7p, which is the bifunctional enzyme of the de novo purine nucleotide biosynthetic pathway. The interaction initially observed in a yeast two-hybrid system was confirmed in vitro with recombinant proteins. Given the complex formation between Ade5,7p and the virulence-regulating Vps34p, it was of interest to characterize the function of Ade5,7p in C. albicans. To this end, ade5,7 null mutants were generated. The resulting mutants were adenine deficient, and sensitive to the presence of metal ions. In addition, the ade5,7 null mutants were avirulent in a mouse model of systemic candidiasis, and showed reduced hyphal growth in an agar matrix under embedded conditions. In summary, Ade5,7p interacts with the multifunctional virulence regulator Ptdlns 3-kinase Vps34p, and ade5,7 and vps34 null mutant strains show similar phenotypes regarding sensitivity to metal ions, hyphal growth and virulence.

\section{INTRODUCTION}

Candida albicans is an opportunistic human fungal pathogen that causes systemic infections in immunocompromised patients, and mucosal infections in healthy individuals (Odds, 1994). The virulence of C. albicans depends on several virulence factors, including the ability to switch between different morphogenetic forms, recognition and adhesion to host epithelial and endothelial cells, and also the secretion of proteinases and phospholipases (Cutler, 1991; Köhler \& Fink, 1996). These virulence factors are affected by the phosphatidylinositol (PtdIns) 3kinase Vps34p, which plays a role in protein transport from the Golgi to the vacuole, and in regulation of virulence factors, such as yeast-to-hyphae transition, adhesion to human cells, and secretion of proteinases. In addition, the

tPresent address: Friedrich Schiller University, Institute of Microbiology - Department of Microbial Phytopathology, Neugasse 25, D-07743 Jena, Germany.

$\ddagger$ Present address: SIRS-Lab GmbH, Winzerlaer Str. 2, D-07745 Jena, Germany.

Abbreviations: $A D$, activation domain of Gal4p; AIRS, aminoimidazole ribotide synthetase; $\mathrm{BD}$, binding domain of the transcription factor Gal4p; EBP, oestrogen-binding protein; FCS, fetal calf serum; GAAC, general amino acid control; GARS, glycinamide ribotide synthetase; GST, glutathione $S$-transferase; P, plasma membrane; Ptdlns, phosphatidylinositol; V, vacuolar; VHHFLU, antibody against fluorescein.
C. albicans vps34 null mutant strain is avirulent in a mouse model of systemic candidiasis (Eck et al., 2000; Bruckmann et al., 2000). The multifunctional Vps34p protein interacts with the vacuolar ATPase subunit Vma7p (Eck et al., 2005), and the overlapping and related functions of these two proteins have been demonstrated by the related phenotypes of the vps34 and the vma7 null mutants. In this study, the Vps34p-interacting protein Ade5,7p was isolated and functionally characterized.

Ade5,7p is a bifunctional enzyme of the de novo purine nucleotide biosynthetic pathway in the yeast Saccharomyces cerevisiae. The de novo purine synthesis pathway involves 10 sequential enzymic steps that result in the generation of inosine monophosphate, followed by one of two paths to produce either adenosine monophosphate or guanosine monophosphate. In bacteria, enzymes involved in de novo purine synthesis are encoded by separate genes, while their eukaryotic counterparts are often encoded by single genes encoding multifunctional polypeptides (Henikoff, 1987; Zalkin \& Dixon, 1992).

At least 13 proteins regulate the synthesis of adenine in $S$. cerevisiae (Jones \& Fink, 1982). Some of these enzymes participate in specific steps of the pathway (encoded by $A D E 1, A D E 2, A D E 4, A D E 5,7, A D E 6, A D E 8, A D E 12$ and $A D E 13)$, while others are required to produce additional substrates necessary to complete the pathway (encoded by 
$A D E 3$ and $A S P 5)$. Strains with mutations in two transcription factor genes, $B A S 1$ and $B A S 2$, show a partial adenine requirement for growth (Arndt et al., 1987). In the latter mutants, expression of the biosynthetic enzymes is low, indicating a positive regulatory role for the transcription factors (Daignan-Fornier \& Fink, 1992). Another transcription factor, Gcn4p, which is positively regulated by Gcn1p, also stimulates the expression of ADE5,7 under conditions of purine limitation (Rolfes \& Hinnebusch, 1993).

In the yeast $S$. cerevisiae, Ade5,7p contains the activities for aminoimidazole ribotide synthetase (AIRS) and glycinamide ribotide synthetase (GARS), which are involved in steps two and five, respectively, of adenine biosynthesis. The deletion of $A D E 5,7$ in $S$. cerevisiae leads to viable mutants that have an adenine requirement, and reduced fitness in rich medium (Giaever et al., 2002).

C. albicans contains an ADE5,7 homologous ORF (ORF 19.5061, IPF13495.2) that is $2409 \mathrm{bp}$ long, and shows $62 \%$ identity to the corresponding S. cerevisiae gene (Arnaud et al., 2005; D'Enfert et al., 2005). This ORF shows high homology to sequences in S. cerevisiae that encode GARS and AIRS enzymic activity. Apparently, C. albicans Ade5,7p expression is regulated in a Gcn4p-independent fashion, in contrast to the S. cerevisiae orthologue (Yin et al., 2004). Increased expression of the Candida ADE5,7 gene has been observed in genome-wide expression profiling as a response to the antimycotic substance 5-flucytosine (Liu et al. 2005).

The deletion of $C$. albicans ADE2 (the gene encoding phosphoribosylaminoimidazole carboxylase) leads to reduced virulence, showing that de novo purine biosynthesis is involved in Candida pathogenicity (Donovan et al., 2001).

Given the physical interaction between the Ade5,7p, which is the bifunctional enzyme of the de novo purine nucleotide biosynthetic pathway, and the virulence-specific Vps34p, we were interested in characterizing the function of Ade5,7p in C. albicans. C. albicans Ade5,7p was cloned and recombinantly expressed, and the interaction of the recombinant Ade5,7p with Vps34p was shown. In addition, ade5,7 null mutants were generated, and these mutant strains were assayed for adenine requirement, detoxification, hyphal development and virulence.

\section{METHODS}

Strains and growth conditions. The C. albicans strains used in this study are listed in Table 1. Yeast strains were grown in YPD medium [2\%(w/v) glucose, $2 \%(\mathrm{w} / \mathrm{v})$ peptone, $1 \%(\mathrm{w} / \mathrm{v})$ yeast extract], YNB [0.7\% (w/v) yeast nitrogen base (Difco), $2 \%(\mathrm{w} / \mathrm{v})$ glucose $]$ or Sabouraud medium $[2 \%(\mathrm{w} / \mathrm{v})$ glucose, $1 \%(\mathrm{w} / \mathrm{v})$ peptone (casein)] at $30^{\circ} \mathrm{C}$. Growth was monitored by counting cell numbers in a haemocytometer. Hyphal growth was induced on solid medium: cells were grown overnight in YPD at $30{ }^{\circ} \mathrm{C}$, washed with $0.9 \mathrm{M} \mathrm{NaCl}$, diluted, and spread either on Spider plates [1\%(w/v) nutrient broth, $0.2 \%(\mathrm{w} / \mathrm{v}) \mathrm{K}_{2} \mathrm{HPO}_{4}, 1.35 \%(\mathrm{w} / \mathrm{v})$ agar, $1 \%(\mathrm{w} / \mathrm{v})$ mannitol] (Lee et al., 1975), or on YPD plates supplemented with $15 \%$ (w/v) fetal calf serum (FCS), at a density of 20-100 cells per plate. Plates were incubated at $37^{\circ} \mathrm{C}$ for at least 7 days. Hyphal growth in liquid medium was induced by 10 -fold dilution of late-exponential-phase cultures grown at $30^{\circ} \mathrm{C}$, either into fresh YPD supplemented with $10 \%(\mathrm{w} / \mathrm{v}) \mathrm{FCS}$, or into Spider medium, at $37^{\circ} \mathrm{C}$. Sensitivities of the mutants to various metal ions were assayed on YPD plates supplemented with the appropriate salts. The ade5,7 mutant strains were selected on CSM (complete supplement mixture) medium (Qbiogene).

Two-hybrid screen. The S. cerevisiae strain Y190 was transformed with the bait plasmid pGBKT34, followed by transformation with the pGAD C. albicans cDNA library (Eck et al., 2005). A lacZ filter assay (Kranz et al., 2001) was performed, and positive clones were isolated by plasmid rescue. All other methods were performed according to standard techniques. The nucleotide sequence of the positive clone was determined, and compared with that of the Stanford C. albicans sequencing project (http://candida.bri.nrc.ca/candida/index.cfm).

Expression of recombinant C. albicans Ade5,7p, ligand blot and pull-down assay. Ade5,7p was recombinantly expressed as a GST (glutathione $S$-transferase) fusion protein (Ade5,7 $7_{\mathrm{GST}}$ ) in Escherichia coli. ADE5,7 cDNA was amplified using primer A (introducing a BamHI site) and primer B (introducing a HindIII site) (Table 2). The PCR product was cleaved with BamHI and HindIII, and cloned into the pGEX3T vector, resulting in plasmid pGEX7-Ade5,7. Subsequent transfection of E. coli, induction of protein expression, and purification, were carried out according to the manufacturer's protocols. In addition, Vps34p was recombinantly expressed as a His6-tagged protein (Vps34 $4_{\mathrm{HIS}}$ ), and C. albicans EBP (oestrogen-binding protein) was expressed as a GST-tagged protein $\left(\mathrm{EBP}_{\mathrm{GST}}\right)$ (Eck et al., 2000; Madani et al., 1994). The fluorescein antibody VHHFlU was expressed as a His6-tagged protein $\left(\mathrm{VHHFLU}_{\mathrm{HIS}}\right)$. For ligand overlay assays, approximately $0.5 \mu \mathrm{g}$ recombinant protein was separated by SDS-PAGE ( $8 \%)$, and blotted on a Protran transfer membrane (Schleicher \& Schuell) by using standard protocols and a previously described method (Eck et al., 2005). The membrane was incubated overnight with recombinant GST-tagged Ade5,7p or $\mathrm{EBP}_{\mathrm{GST}}\left(8 \mu \mathrm{g} \mathrm{ml}^{-1}\right)$, and then for $2 \mathrm{~h}$ with anti-mouse GST antiserum (1:4000; Amersham Biosciences Europe). After incubation with a secondary monoclonal peroxidaselabelled anti-mouse IgG antibody (1:4000), the blot was developed by using the ECL detection system. Pull-down assays were done according to a previously described method (Eck et al., 2005). Approximately $2.5 \mu \mathrm{g} \mathrm{Vps} 34_{\mathrm{HIS}}$ protein was added to a Ni-NTA superflow agarose column (Qiagen). After washing, a $2.0 \mu \mathrm{g}$ quantity of Ade $5,7_{\mathrm{GST}}, \mathrm{EBP}_{\mathrm{GST}}$ or GSTp was added. The eluate was separated by SDS-PAGE. After blotting, the filter was incubated with mouse GST antiserum ( $1: 3000)$, and developed by ECL.

Deletion of the ADE5,7 gene by PCR-based gene targeting. Primers used in this study are listed in Table 2. The method was performed according to Gola et al. (2003). Marker genes were amplified by primers $\mathrm{S} 1$ [bp -94 (upstream) to +7 of $A D E 5,7]$ and S2 (bp -101 to -1 , downstream of $A D E 5,7$ ). The proper deletion of the complete ADE5,7 ORF (2409 bp, 802 aa; the Stanford C. albicans sequencing project Assembly 19, ORF19.5061 on Contig10218; http:// candida.bri.nrc.ca/candida/index.cfm) was confirmed by Southern analysis, according to standard protocols. The probe was amplified by PCR using primers AS5 (bp - 1318 to -1294 , upstream of ADE5,7) and AS4 (bp -8 to -31 , upstream of $A D E 5,7$ ).

Reintegration of $\boldsymbol{A D E 5 , 7}$. To construct the template for homologous reintegration of the $A D E 5,7$ gene, the primers G1 (bp -577 to -558 , upstream of $A D E 5,7)$ and G4 (bp -498 to -518 , downstream of $A D E 5,7)$ (Table 2; chromosomal sequences are underlined, and 
Table 1. Strains used in this study

\begin{tabular}{|c|c|c|}
\hline Strain & Genotype & Reference/source \\
\hline E. coli XL1-Blue & $\begin{array}{l}\text { supE44 hsdR17 recA1 endA1 gyrA46 } \\
\text { thi relA1 lac } \mathrm{F}^{\prime}\left[\text { proAB }^{+} \text {lacl }{ }^{\mathrm{q}} \Delta \mathrm{M} 15 \mathrm{Tn} 10\left(\text { tet }^{r}\right)\right]\end{array}$ & Stratagene \\
\hline C. albicans SC5314 & Wild-type & Fonzi \& Irwin (1993) \\
\hline C. albicans BWP17 & 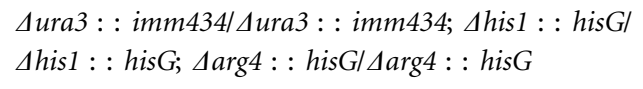 & Wilson et al. (1999) \\
\hline C. albicans $\mathrm{CNC} 44$ & 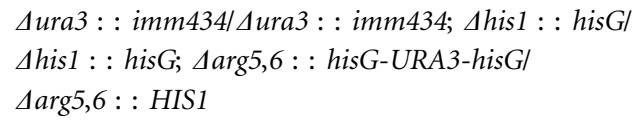 & Negredo et al. (1997) \\
\hline C. albicans $\mathrm{AU}$ & 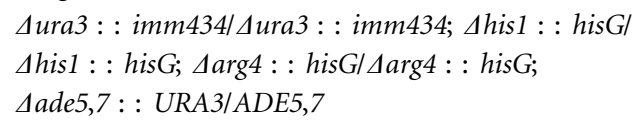 & This work \\
\hline C. albicans $\mathrm{AH}$ & 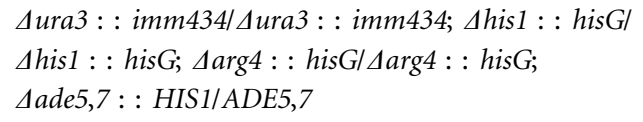 & This work \\
\hline C. albicans AUH & 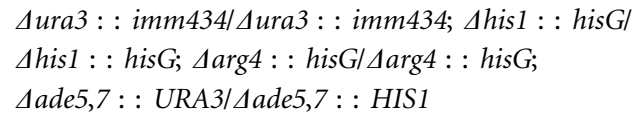 & This work \\
\hline C. albicans AHU & 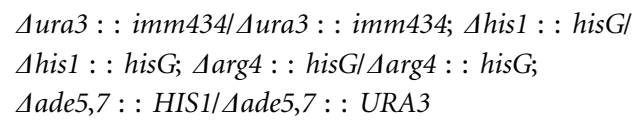 & This work \\
\hline C. albicans AUR & 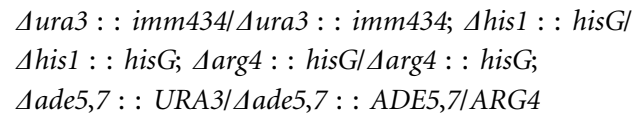 & This work \\
\hline C. albicans $\mathrm{AU}(\mathrm{HA})$ & 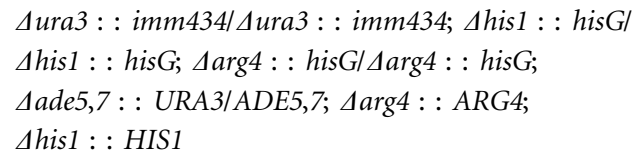 & This work \\
\hline C. albicans AUH(A) & 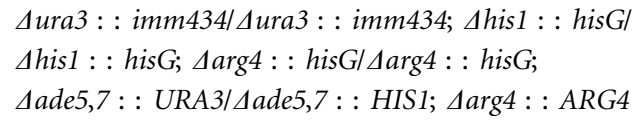 & This work \\
\hline C. albicans $\mathrm{AHU}(\mathrm{A})$ & 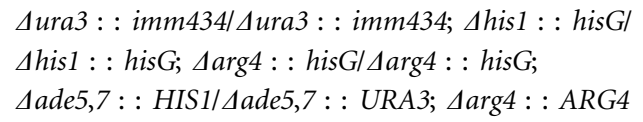 & This work \\
\hline
\end{tabular}

BamHI restriction sites are double underlined) were used to amplified a $3.5 \mathrm{~kb}$ fragment that contained the complete ADE5,7 gene. The PCR product was digested with $B a m \mathrm{HI}$, and integrated into pUC19 (pUCADE). The primers A1 (bp -597 to -578 , upstream of ARG4) and A2 (bp -157 to -176 , downstream of $A R G 4$ ) were used to amplify the selection marker gene ARG4. The PCR product $(2.2 \mathrm{~kb})$ was restricted with $P m a C I$, and integrated $210 \mathrm{bp}$ downstream of $A D E 5,7$ into the plasmid pUCADE. After digestion with BamHI, a $5.7 \mathrm{~kb}$ DNA fragment, containing the $A D E 5,7$ gene with upstream and downstream sequences for homologous recombination, as well as the $A R G 4$ gene as selectable marker, was used to integrate the ADE5,7 gene into the original locus. Reintegrates were selected on plates that did not contain arginine. Proper integration of ADE5,7 was confirmed by PCR and Southern analysis.

Construction of prototrophic mutant strains. To construct the prototrophic heterozygous mutant strain $\mathrm{AU}(\mathrm{HA})$, the primers His1 (bp -764 to -742 , upstream of HIS1), His2 (bp -749 to -727 , downstream of HIS1), Arg1 (bp -992 to -971, upstream of ARG4) and Arg2 (bp -932 to -911 , downstream of $A R G 4$ ) were used. The PCR products of $2410 \mathrm{bp}$ (HIS1) and $3338 \mathrm{bp}$ (ARG4) were used to integrate the HIS1 and ARG4 genes into the original sites by homologous recombination in a two-step procedure. To construct prototrophic ade5,7 null mutant strains $\mathrm{AHU}(\mathrm{A})$ and $\mathrm{AUH}(\mathrm{A})$, the primers Arg1 and Arg2 were used. Proper integration of the HIS1 and $A R G 4$ genes was tested by Southern analysis.

Hyphal induction within agar matrix. For filamentous growth within an agar matrix, C. albicans strains were grown overnight in YPD, and diluted to $5 \times 10^{6}$ cells $\mathrm{ml}^{-1}$. After growth for $4 \mathrm{~h}$ at $30^{\circ} \mathrm{C}$, the culture was diluted to $10^{3} \mathrm{cells}^{-1}$. A $100 \mu \mathrm{l}$ volume of the diluted cells was mixed with YPS agar [1\%(w/v) yeast extract, $2 \%$ $(\mathrm{w} / \mathrm{v})$ peptone (blood), $2 \%(\mathrm{w} / \mathrm{v})$ sucrose, and $1 \%(\mathrm{w} / \mathrm{v})$ agar-agar], and poured into plates. After 48, 96, 144, 192 and $240 \mathrm{~h}$ incubation at $23{ }^{\circ} \mathrm{C}$, colonies were examined microscopically, and the percentage of filamentous colonies was plotted as a function of time.

Virulence studies. Six-week-old male outbred NMRI mice (HarlanWinkelmann) were housed five per cage, and checked daily. The various strains of C. albicans were grown in Sabouraud glucose broth at $30{ }^{\circ} \mathrm{C}$ until late-exponential phase. Cells were washed three times, and resuspended in $0.9 \% \mathrm{NaCl}$. A $200 \mu \mathrm{l}$ suspension, containing between $5 \times 10^{6}$ and $5 \times 10^{5}$ cells (for quantification of kidney colonization after 3 days), or $5 \times 10^{4}$ cells (for quantification of kidney colonization after 21 days), was used to infect immunocompetent mice by intravenous injection into the lateral tail vein. Survival 
Table 2. Primers used in this study

\begin{tabular}{|c|c|}
\hline Primer & Sequence $\left(5^{\prime} \rightarrow 3^{\prime}\right)^{*}$ \\
\hline A & CGGGATCCGAAAAACGTAAATTGGTGGCAGC \\
\hline B & CCCAAGCTTATGTGGAAACTCCAAATTGACTA \\
\hline S1 & CATCGATTAGATTCAAAATCTTAGAAACTTCTCCAAAACTTATTCATT \\
\hline & TGAGATTTTTATTGAATATATTCCCCAACACAATTCAGCTTTAACTATGTCATGAAGCTTCGTACGCTGCAGGTC \\
\hline S2 & $\begin{array}{l}\text { ATATAATAATTTAAACATACAAAAGCAAGCAGTAAACAACAACAACAACAACAACAACAACCTCAATCGTCTAGT- } \\
\text { TGTAATATCAACATTTCTTATTTTCTTCTGATATCATCGATGAATTCGAG }\end{array}$ \\
\hline AS4 & GCTGAATTGTGTTGGGGAATATAT \\
\hline AS5 & AGAATGTTAAAACCAGGGGACATCT \\
\hline G1 & $\overline{\text { ATCCGCGGATCCAAGGGTTGTGACACCTAATG }}$ \\
\hline G4 & ATGCGCGGATCCACTCAAAGCCGAGATAGACCT \\
\hline A1 & ATCGATCGCACGTGGGAATCACTTTTTGGATGAA \\
\hline A2 & ATCGATCG $\overline{\overline{\text { CACGTG }} \text { CATATAGACGTGTTGTGTGT }}$ \\
\hline Arg1 & GAAACAATGAATCGATGCTTTC \\
\hline Arg2 & $\overline{\text { CCTTGGTATTAGGTGATTTTGC }}$ \\
\hline His1 & CTCGTGCCGTGTTGAATGTTTGC \\
\hline His2 & CAGAACGCTCCGCACAAAAATC \\
\hline
\end{tabular}

${ }^{\star}$ Chromosomal sequences are underlined; restriction sites are double underlined.

was monitored for 19-21 days. For comparison of survival curves, the log-rank test was used (Peto et al., 1977). A $P$ value $\leqslant 0.05$ was considered to be significant.

To quantify kidney colonization of C. albicans, mice were sacrificed 3 days (infected with $5 \times 10^{5}$ cells) and 21 days (infected with $5 \times 10^{4}$ cells) after injection, and kidneys were homogenized in $3 \mathrm{ml}$ physiological $\mathrm{NaCl}$ buffer. Serially diluted suspensions were then plated on YPD agar. After 4 days growth at $30^{\circ} \mathrm{C}$, numbers of $C$. albicans colonies were counted. The studies using embryonated hen eggs as an alternative virulence model were done according the method described for Pseudomonas aeruginosa and C. albicans (Härtl et al., 1995, 1997).

\section{RESULTS}

\section{C. albicans Vps34p interacts with Ade5,7p, which is the bifunctional enzyme of the de novo purine nucleotide biosynthetic pathway}

Vps34p-interacting Candida proteins were identified using the yeast two-hybrid system. The bait protein Vps34p was expressed in S. cerevisiae Y190/pGBKT34, which was transformed with a $C$. albicans cDNA library inserted into the prey vector. A positive clone containing a $1.2 \mathrm{~kb}$ insert was selected by lac $Z$ filter assay (data not shown). The sequence of the insert was determined. It contains an ORF of $1005 \mathrm{bp}$ that starts $41 \mathrm{bp}$ downstream of the $B a m H I$ restriction site and is in-frame with the GAL4 activation domain. The corresponding protein is 334 aa, and shows approximately $65 \%$ identity to the C-terminal end of Ade5,7p of $S$. cerevisiae. In addition, the sequence is identical to the ADE5,7 ORF of the Stanford C. albicans sequence (Assembly 19, ORF19.5061 on Contig10219, 802 aa). This ORF shows a $62 \%$ similarity to the corresponding $S$. cerevisiae gene. We conclude that the identified clone represents the Candida homologue of $S$. cerevisiae ADE5,7.

The interaction of the truncated Ade5,7p and Vps34p was confirmed by retransformation and subsequent lac $Z$ filter assays, and expression analysis of the HIS1 reporter gene, in different $S$. cerevisiae two-hybrid strains that contained different promoter constructs of the reporter genes.

First, the interaction was confirmed by the retransformation of ADE5,7 into S. cerevisiae Y190/pGBKT34. All isolated colonies were blue, showing the expression of the lac $Z$ gene that is induced by the interaction of $\mathrm{BD}$ (binding domain of the transcription factor Gal4p)-Vps34p and AD (activation domain of Gal4p)-Ade5,7p. In contrast, the control that lacked $\mathrm{AD}$-Ade5,7p remained white, and this indicated that BD-Vps34p was not able to induce the transcription of lac $Z$ reporter without AD-Ade5,7p (data not shown).

Second, we tested the expression of the HIS reporter genes in S. cerevisiae Y190 and HF7c. The interaction of Vps34p with Ade5,7p induced expression of these reporter genes, and resulted in growth on histidine-deficient solid medium (Fig. 1). S. cerevisiae strains lacking one of the two interacting proteins were unable to grow on plates without histidine, and this confirmed that the interaction between $\mathrm{BD}-\mathrm{Vps} 34 \mathrm{p}$ and $\mathrm{AD}-\mathrm{Ade} 5,7 \mathrm{p}$ induced the transcription of the histidine reporter genes (Fig. 1).

\section{Biochemical characterization of the Vps34p-Ade5,7p interaction}

The complete protein Ade5,7p was recombinantly expressed as a GST fusion protein, and Vps34p was fused with a His6 tag. Both recombinant proteins were isolated 


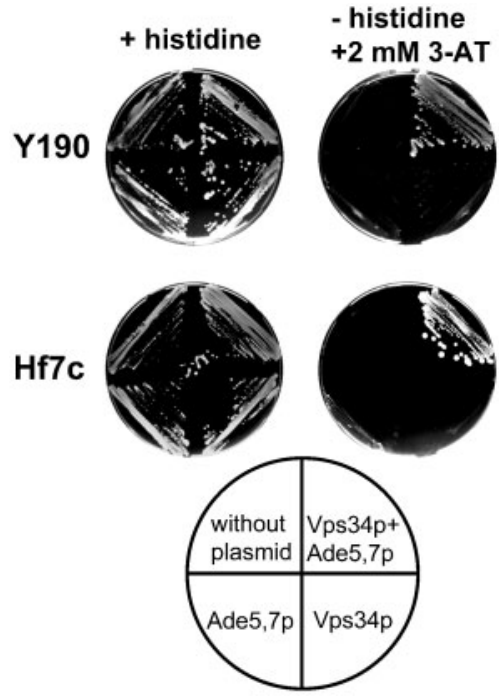

Fig. 1. C. albicans Vps34p interacts with Ade5,7p. The expression of the HIS reporter gene in S. cerevisiae Y190 and HF7c, caused by the interaction of Vps34p with Ade5,7p, results in growth on His-deficient solid medium $\left(30{ }^{\circ} \mathrm{C}, 24 \mathrm{~h}\right)$. The proteins alone do not induce the expression of the HIS reporter gene. 3-AT, 3-amino-1,2,4-triazol.

by affinity chromatography. Recombinant Ade $5,7_{\mathrm{GST}}$, with a mobility of $125 \mathrm{kDa}$, reacted with GST antiserum (Fig. 2A, lane 2), and the $115 \mathrm{kDa} \mathrm{Vps} 34_{\mathrm{HIS}}$ reacted with His antiserum, but not with GST antiserum (Fig. 2A, lanes 1 and 3). Direct physical interaction of the recombinant proteins was shown using a ligand blot and a pull-down approach.

For the ligand overlay, the recombinant denatured proteins Ade $5,7_{\mathrm{GST}}$ and Vps34 $4_{\mathrm{HIS}}$ were blotted onto a membrane, and incubated with Ade5,7 GST (Fig. 2B, lanes 1 and 2). The denaturation reduced the chance of interaction. Nevertheless, the binding of Ade $5,7_{\mathrm{GST}}$ to immobilized Vps34 $4_{\text {HIS }}$ was detected by anti-mouse GST antiserum (Fig. 2B, lane 2). This interaction was specific, as the $\mathrm{EBP}_{\mathrm{GST}}$ control protein did not bind to the immobilized Vps34 $4_{\text {HIs }}$ protein (Fig. 2B, lane 4), and the VHHFLU control protein did not bind to the immobilized Ade5,7 $7_{\mathrm{GST}}$ protein (Fig. 2B, lane 5).

For the pull-down assay, the Vps34 $4_{\text {HIS }}$ protein was immobilized to a nickel matrix, and Ade $5,7_{\mathrm{GST}}$ protein was applied. In the eluate fraction, Ade $5,7_{\mathrm{GST}}$ was identified (Fig. 2C, lane 1), thus demonstrating binding of Ade5,7p to Vps34p. When Ade5,7 $7_{\mathrm{GST}}$ was applied to a nickel matrix in the absence of $\mathrm{Vps} 34_{\mathrm{HIS}}$, no binding was detected (Fig. 2C, lane 2). Nonspecific binding of GSTp or other proteins was excluded by analysing the application of GSTp protein alone, and the recombinant $\mathrm{EBP}_{\mathrm{GST}}$ protein, on the column with Vps34 3 Hs. The eluate fraction did not contain any control proteins, thus excluding the possibility of nonspecific binding (Fig. 2C, lanes 3 and 4).

\section{Disruption of the ADE5,7 gene in C. albicans}

The ADE5,7 null mutant strains of $C$. albicans BWP17 were generated to characterize the role of the putative purine nucleotide biosynthesis enzyme Ade5,7p in C. albicans. As a first step, two heterozygous mutants were generated that contained either the URA3 (AU) or the HIS1 (AH) gene as a selectable marker integrated at the $A D E 5,7$ loci. As the absence of an URA3 allele makes the interpretation of mutant phenotypes more difficult (Lay et al., 1998; Cheng et al., 2003), the URA3 gene containing heterozygous mutant strain AU was used to assay the phenotypes.

In the heterozygous strains $\mathrm{AU}$ and $\mathrm{AH}$, the second $A D E 5,7$ allele was replaced by the HIS 1 gene, resulting in $\mathrm{AUH}$, and by the URA3 gene, resulting in AHU (Fig. 3A). Proper deletion of the $A D E 5,7$ genes in all strains was confirmed by Southern analysis (Fig. 3C), and by PCR (data not shown). Chromosomal DNA of the C. albicans strains SC5314 (wild-type), CNC44 ( Arg $^{-}$), BWP17 (parental strain) and the various mutant strains was isolated, and restricted with $\mathrm{NdeI}$. The proper $8.8 \mathrm{~kb}$ wild-type fragment in C. albicans SC5314, CNC44 and BWP17 was identified by Southern hybridization (Fig. 3C, lanes 1, 2 and 3). The replacement of one $A D E 5,7$ allele by the URA3 gene (AU; Fig. 3C, lane 4) or the HIS1 gene (AH; Fig. 3C, lane 5) resulted in an additional fragment of 2.2 or $7.9 \mathrm{~kb}$, respectively. The replacement of the second $A D E 5,7$ allele by the HIS1 (Fig. 3C, lane 6) or URA3 gene (Fig. 3C, lane 7) led to two ade5,7 null mutants (AUH and AHU, respectively). The loss of the $8.8 \mathrm{~kb}$ fragment was consistent with the replacement of the second allele (Fig. 3C).

The identical phenotypes of two independently constructed ade5,7 null mutants showed that $A D E 5,7$ was indeed the cause of the changed phenotypes. To confirm this, an $A D E 5,7$ reintegrate strain, AUR, was generated by replacing the HIS1 gene in the null mutant strain AUH with the $A D E 5,7$ gene and the $A R G 4$ gene (Fig. $3 \mathrm{~B}$ ). The $5.1 \mathrm{~kb}$ band shows the proper integration of $A D E 5,7$ fused with $A R G 4$ (Fig. 3C, lane 8). The correct deletion of $A D E 5,7$, and the reintegration of $A D E 5,7$ and $A R G 4$, were also confirmed by PCR (data not shown).

\section{Role of Ade5,7p in adenine biosynthesis and metal-ion homeostasis}

Ade5,7p is essential for the biosynthesis of adenine. The ade5,7 null mutant strains AUH and AHU did not grow on plates that did not contain adenine (Fig. 4A).

$\mathrm{Vps} 34 \mathrm{p}$ is involved in the sequestration of toxic ions via a $\mathrm{H}^{+}$gradient, in cooperation with the vaculoar ATPase (Kitanovic et al., 2005; Eck et al., 2005). Therefore, the effect of the Vps34p-interacting protein Ade5,7p on metalion homeostasis was assayed. We tested whether and how metal ions influenced the growth of the C. albicans ade5,7 null mutant strains AUH and AHU. The C. albicans wildtype strain and the ade5,7 mutant strains showed equal growth on plates supplemented with $\mathrm{Co}^{2+}$. The same 
A

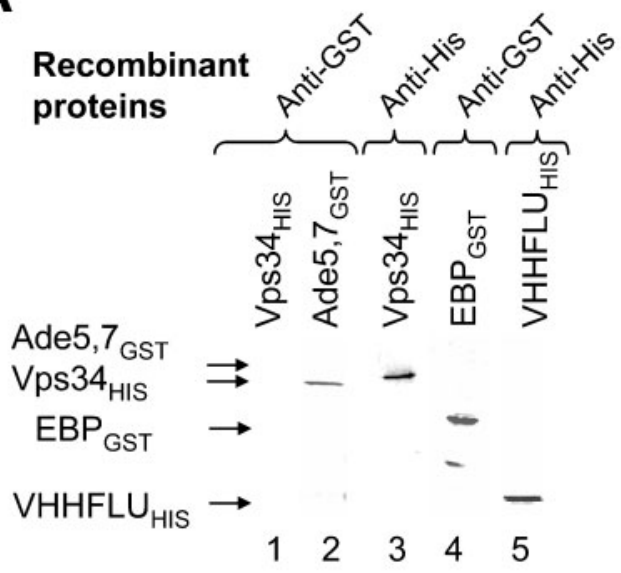

B

Ligand blot
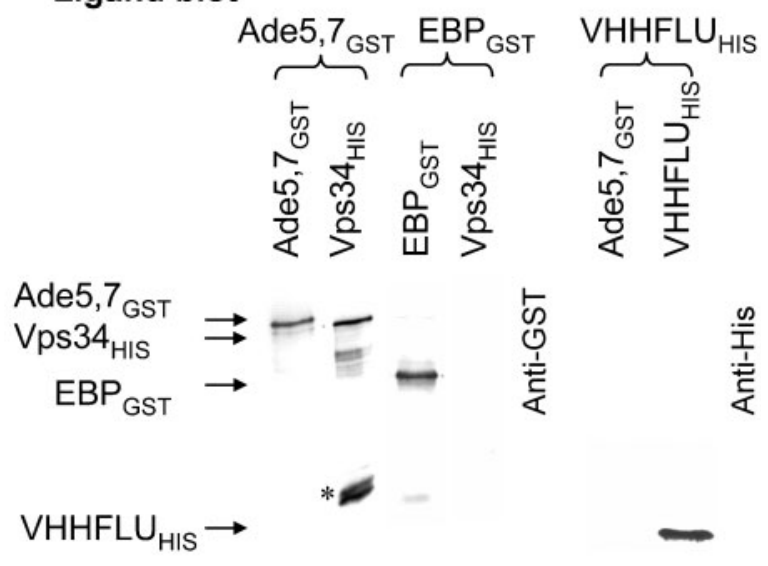

$\begin{array}{llll}1 & 2 & 3 & 4\end{array}$

56

C

His-pull down
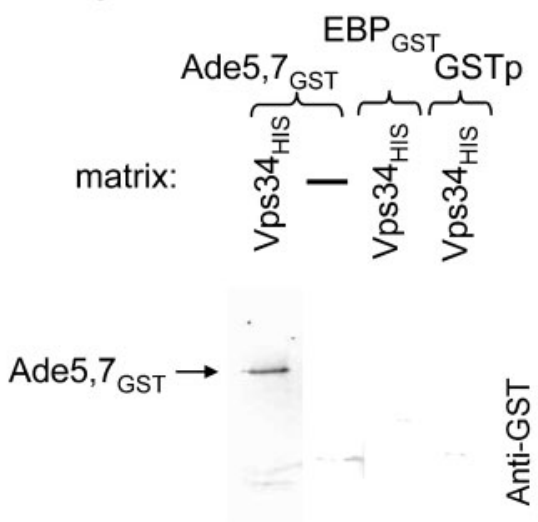

$\begin{array}{llll}1 & 2 & 3 & 4\end{array}$

results were found for plates supplemented with $\mathrm{Mn}^{2+}$, $\mathrm{Ni}^{2+}$ or $\mathrm{Zn}^{2+}$ (data not shown). However, on plates supplemented with $\mathrm{Cu}^{2+}$ and $\mathrm{Ag}^{2+}$, the ade5,7 null mutants showed increased sensitivity towards high ion
Fig. 2. C. albicans Vps34p interacts in vitro with Ade5,7p. (A) Recombinant Ade5, $7_{\mathrm{GST}}\left(125.0 \mathrm{kDa}\right.$, lane 2), $\mathrm{Vps} 4_{\mathrm{HIS}}$ (120.0 kDa, lane 3), $\operatorname{EBP}_{\mathrm{GST}}(81 \mathrm{kDa}$, lane 4), and VHHFLU HIS $(10 \mathrm{kDa})$. Vps34 3 HIS does not show cross-reactivity with anti-GST (lane 1). Ade5, $7_{\mathrm{GST}}$ and the control protein $\mathrm{EBP}_{\mathrm{GST}}$ react with anti-GST (lanes 2 and 4). Vps34 $4_{\text {HIS }}$ and the control protein VHHFLU ${ }_{\text {HIS }}$ react with anti-His (lanes 3 and 5). (B) Ligand blot. Membranes loaded with Ade5, $7_{\mathrm{GST}}$ and $\mathrm{Vps} 34_{\mathrm{HIS}}, \mathrm{EBP}_{\mathrm{GST}}$ and $\mathrm{Vps} 34_{\mathrm{HIS}}$, or Ade $5,7_{\mathrm{GST}}$ and $\mathrm{VHHFLU} \mathrm{HIS}_{\mathrm{HS}}$ were incubated with indicated proteins

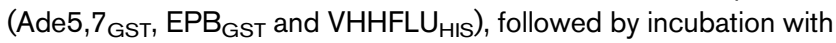
anti-GST or anti-His. The asterisk marks possible degradation products of Vps34 HIs. (C) His pull-down. Ni-NTA beads loaded with $\mathrm{Vps}_{3} 4_{\text {HIS }}$ (lanes 1, 3 and 4) and unloaded (lane 2) were incubated with Ade5,7 $7_{\mathrm{GST}}$ (lanes 1 and 2), EBP $\mathrm{GST}$ (lane 3), and GSTp alone (lane 4), under native conditions. The eluted proteins were separated by SDS-PAGE, blotted, and detected by anti-GST. The correct sizes of recombinant proteins were checked by protein markers (not shown).

concentrations, thus demonstrating a moderate role of Ade5,7p in ion detoxification (Fig. 4B-D).

The growth of the ade5,7 mutants was inhibited by $\mathrm{AgNO}_{3}$ at a concentration of $750 \mu \mathrm{M}, \mathrm{CuSO}_{4}$ at $15 \mathrm{mM}$, and $\mathrm{CuCl}_{2}$ at $4 \mathrm{mM}$. The vps34 null mutant strain CAV3 showed similar sensitivity to $\mathrm{AgNO}_{3}, \mathrm{CuSO}_{4}$ and $\mathrm{CuCl}_{2}$ (Fig. 4B-D).

\section{C. albicans ade5,7 null mutant shows repressed filamentous growth under low-temperature embedded conditions}

Multiple pathways have been shown to regulate the induction of hyphal growth in C. albicans; these include the MAP kinase, the cAMP, the $\mathrm{pH}$-regulated, and the embedded/microaerophilic pathways (Köhler \& Fink, 1996; Brown et al., 1999; Davis et al., 2000; Ernst, 2000; Giusani et al., 2002). The C. albicans ade5,7 null mutant strains showed the same characteristics as the wild-type strains when hyphal growth was induced via the MAP kinase pathway, the cAMP pathway, and the pH-regulated pathway (data not shown). Consequently, an additional yeast-to-hyphae transition, which is induced by embedded/ microaerophilic conditions, was analysed. The hyphal growth in an agarose matrix at low temperature $\left(23^{\circ} \mathrm{C}\right)$ was tested. After $144 \mathrm{~h}$, the AUH and AHU ade5,7 null mutant strains showed $10 \%$ and $20 \%$ filamentous colonies, respectively, while the percentage of filamentous colonies was $100 \%$ for the wild-type strains SC5314 and CNC44. In addition, the heterozygous mutant AU showed approximately $30 \%$ filamentous colonies, and the AUR revertant strain showed $13 \%$ filamentous colonies (Fig. 5A). After 10 days, approximately $80 \%$ of the colonies of the null mutant strain exhibited hyphal growth, whereas the wild-type strains, the heterozygous mutant strain AU, and the revertant strain, showed $90-100 \%$ filamentous colonies.

In addition, the colonies differed in mycelial phenotype after 6 days $(144 \mathrm{~h})$. The wild-type strains SC5314 and 


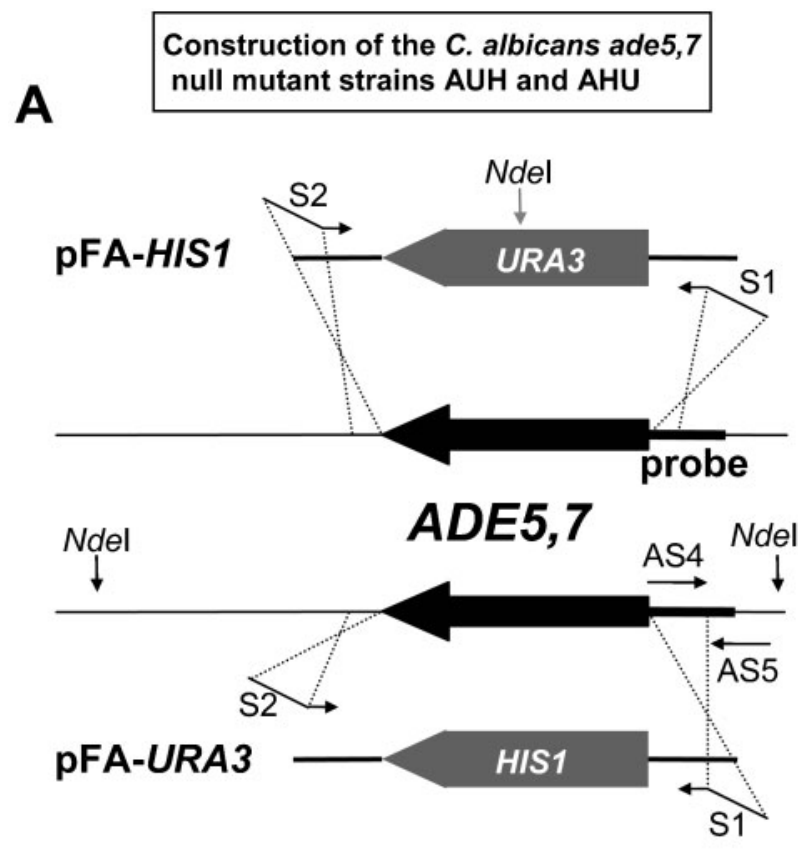

B

Genotype of the $C$. albicans $A D E 5,7$ revertant strain AUR
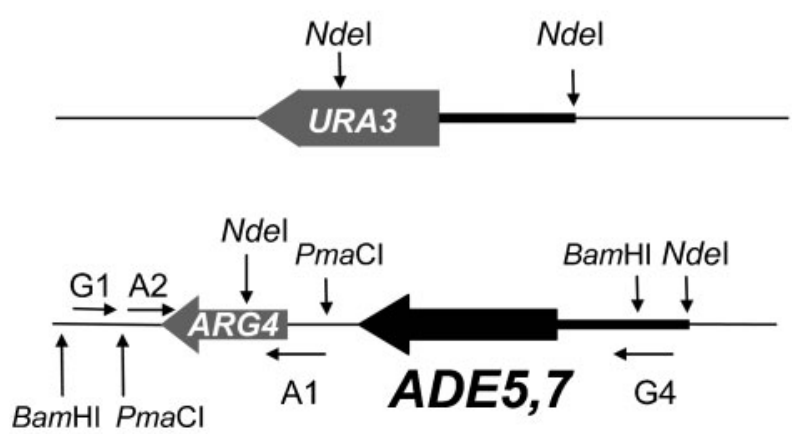

C

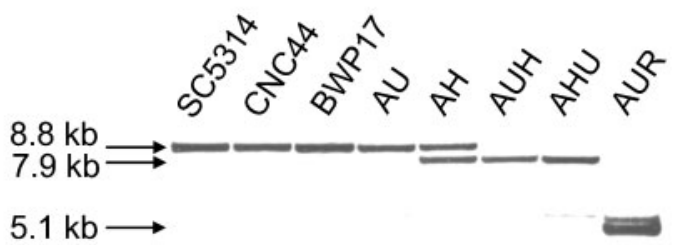

$2.2 \mathrm{~kb} \longrightarrow$
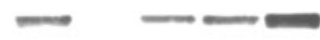

$\begin{array}{llllllll}1 & 2 & 3 & 4 & 5 & 6 & 7 & 8\end{array}$

CNC44 exhibited intensive mycelial growth of the colonies. The heterozygous mutant AU and the revertant AUR colonies showed slightly reduced filamentous growth, and
Fig. 3. Disruption of the $A D E 5,7$ gene in C. albicans. The strategies used $(\mathrm{A})$ to replace the chromosomal $A D E 5,7$ genes by URA3 and HIS1 genes, and (B) to reintegrate the ADE5,7 gene, resulting in $C$. albicans revertant strain AUR, are shown. Thick black arrows indicate the ADE5,7 gene; S1, S2, G1, G4, AS4, AS5, A1 and A2 are PCR primers (Table 2), pFA-URA3 and pFAHIS3 are plasmids used for PCR with $S 1$ and S2; Ndel is the restriction enzyme used for Southern analysis; $\mathrm{PmaCl}$ is the restriction enzyme used for cloning of $A R G 4 ; B a m H I$ is the restriction enzyme used for cloning of $A D E 5,7(\mathrm{~A}, \mathrm{~B})$. (C) Southern analysis of Ndel-digested chromosomal DNA from the following $C$. albicans strains: wild-type strain SC5314 (lane 1); $\mathrm{Arg}^{-}$strain CNC44 (lane 2); parental strain BWP17 (lane 3); AU mutant strain (heterozygous $A D E 5,7 / a d e 5,7$ mutant strain with integrated URA3 gene, lane 4), $\mathrm{AH}$ mutant strain (heterozygous $A D E 5,7 /$ ade5,7 mutant strain with integrated HIS1 gene, lane 5), AUH mutant strain (homozygous ade5,7 null mutant strain, lane 6), AHU mutant strain (homozygous ade5,7 null mutant strain, lane 7), AUR revertant strain (heterozygous ADE5,7-ARG4/ade5,7 revertant strain, lane 8 ). The blot was hybridized with non-radioactive labelled PCR product, which was obtained with primers AS4 and AS5.

the colonies of the null mutant strains AHU and AUH showed few mycelial structures (Fig. 5B).

\section{Ade5,7p is required for virulence of $C$. albicans}

The ade5,7 null mutants showed affected hyphal development under microaerophilic/embedded conditions. Consequently, the virulence of the mutant strains was tested in a mouse model of systemic candidiasis. All ade5,7 null mutants were avirulent in this animal model, and resulted in a significantly higher survival of infected mice compared with the wild-type strain and the $\mathrm{Arg}^{-}$strain CNC44. All mice infected with $5 \times 10^{6}$ mutated AUH, $\mathrm{AHU}, \mathrm{AUH}(\mathrm{A})$ and $\mathrm{AHU}(\mathrm{A})$ C. albicans cells survived during the complete course of the experiment (Fig. 6A, B) and looked healthy. The heterozygous mutant strains AU and $\mathrm{AU}(\mathrm{HA})$, and the $A D E 5,7$ revertant strain AUR, showed slightly, non-significant, reduced virulence, and $70-80 \%$ of the infected mice survived. However, most of these animals (75-90\%) lost weight, rotated, or showed a crooked neck. All mice infected with $5 \times 10^{6}$ wild-type cells SC5314 died after 6 days.

Contrasting results were observed in the alternative virulence model of embryonated hen eggs. Most embryos (80-90\%) of the eggs infected with $10^{8}$ null mutant cells died after 2 days. The wild-type strain SC5314, the heterozygote strain, and the revertant strain, showed similar significantly higher virulence. Only embryos of control eggs inoculated with $\mathrm{NaCl}$ survived (Fig. 6C).

Systemic candidiasis is often associated with colonization of internal organs, such as kidneys, lung or liver. It is known that in animal models of disseminated candidiasis, C. albicans exhibits a high predilection for the kidneys, which leads to late fatalities in the course of the infection 
(Odds, 1994). Therefore, kidney colonization of mice infected with $5 \times 10^{5}$ cells of the strains SC5314, AU, AUH, AHU and AUR was examined 3 days post-infection $(n=2)$. Kidneys of mice bearing strain SC5314 exhibited a high fungal burden of between $4.1 \times 10^{4}$ and $7.9 \times 10^{4}$ c.f.u.

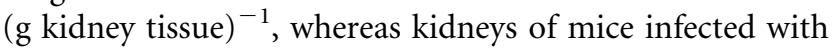
the null mutants $\mathrm{AHU}$ and $\mathrm{AUH}$ showed reduced c.f.u. $\left[0.0-6.0 \times 10^{2}\right.$ and $2.0 \times 10^{3}$ (g kidney tissue) ${ }^{-1}$, respectively]. The heterozygote mutant and the revertant strains

\section{A}

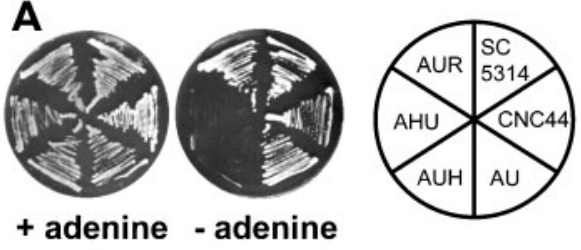

B

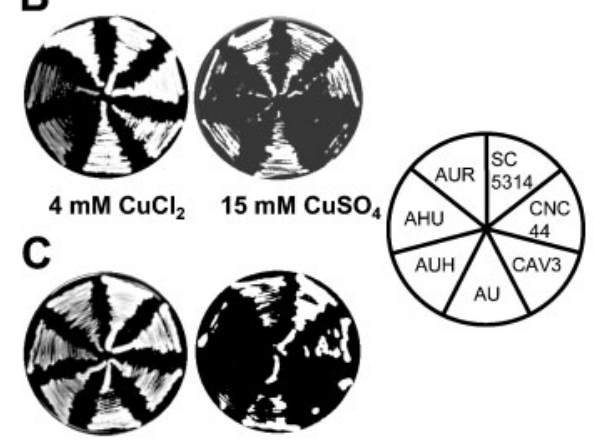

$0.1 \mathrm{mM} \mathrm{AgNO}_{3} \quad 0.75 \mathrm{mM} \mathrm{AgNO}_{3}$
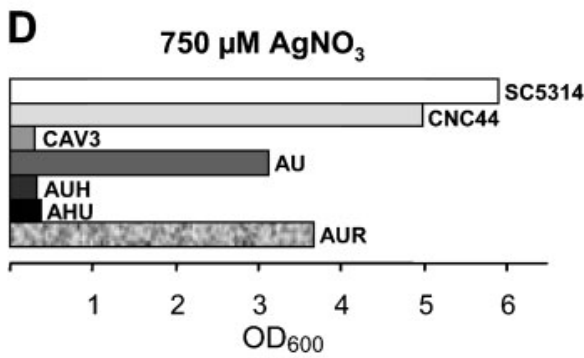

Fig. 4. ade5,7 null mutants show adenine auxotrophy, and increased sensitivities to metal ions. (A) C. albicans ade5,7 null mutant strains $\mathrm{AUH}$ and $\mathrm{AHU}$ show reduced growth on solid medium lacking adenine. (B-D) ade5,7 null mutant strains $A U H$ and $\mathrm{AHU}$, and the vps34 null mutant strain $\mathrm{CAV} 3$, show increased sensitivity to (B) $\mathrm{CuCl}_{2}, \mathrm{CuSO}_{4}$ and (C) $\mathrm{AgNO}_{3}$ on solid medium, and $(D)$ in liquid medium after growth for 48 h. The C. albicans wild-type strains SC5314 and CNC44, the heterozygous mutant strain $A U$ and the $A D E 5,7$ revertant strain AUR grew equally well on solid medium lacking adenine. The same results were shown on solid and in liquid medium supplemented with $\mathrm{AgNO}_{3}$ and on solid medium supplemented with $\mathrm{CuCl}_{2}$ and $\mathrm{CuSO}_{4}$, respectively. showed slightly higher c.f.u. than the null mutant strains [between $0.4 \times 10^{3}$ and $5.1 \times 10^{3}$, and $2.0 \times 10^{2}$ and $3.0 \times 10^{2}$ (g kidney tissue) ${ }^{-1}$, respectively].

In addition, survivors of the virulence test were checked for kidney colonization. Examination of kidney colonization was assayed after 21 days for mice infected with $5 \times 10^{4}$ cells. Kidneys of mice bearing strain SC5314 exhibited a high fungal burden of between $0.9 \times 10^{6}$ and $1.0 \times 10^{6}$ c.f.u.

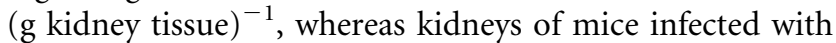
the null mutant strains AUH and AHU showed a slightly reduced number of c.f.u. [between $1.4 \times 10^{5}$ and $8.2 \times 10^{5}$, and $1.0 \times 10^{4}$ and $1.1 \times 10^{6}$ (g kidney tissue) ${ }^{-1}$, respectively]. The kidneys of mice infected with the heterozygous strain and the revertant strain exhibited nearly identical numbers of c.f.u. to the wild-type strain SC5314 [between $0.9 \times 10^{6}$ and $2.9 \times 10^{6}$, and $1.2 \times 10^{6}$ and $4.9 \times 10^{6}$

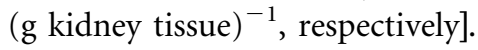

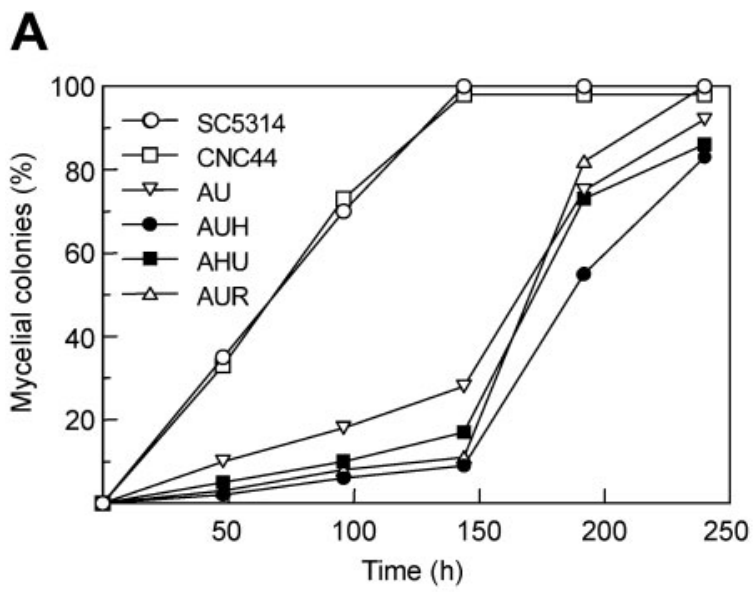

B

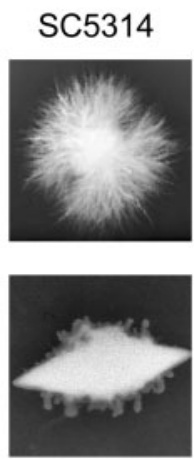

$\mathrm{AUH}$
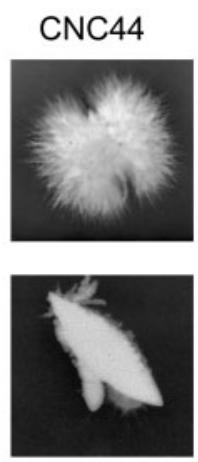

$\mathrm{AHU}$
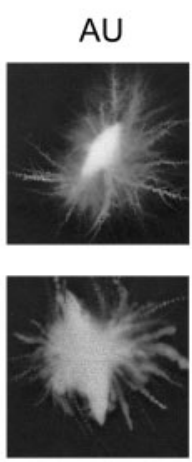

AUR
Fig. 5. Ade5,7p is essential for hyphal development under microaerophilic/embedded conditions. After different incubation times at $23{ }^{\circ} \mathrm{C}$, colonies were examined microscopically, and the percentage of filamentous colonies was plotted as a function of time. (A) The ade5,7 null mutant strains AUH and AHU showed a reduced number of filamentous colonies. (B) The colonies differed in mycelial phenotype after 6 days incubation. 
These results clearly show reduced numbers of c.f.u. after 3 days in the kidneys of mice bearing the null mutant strains, and the heterozygous and revertant strains, whereas after

\section{A}

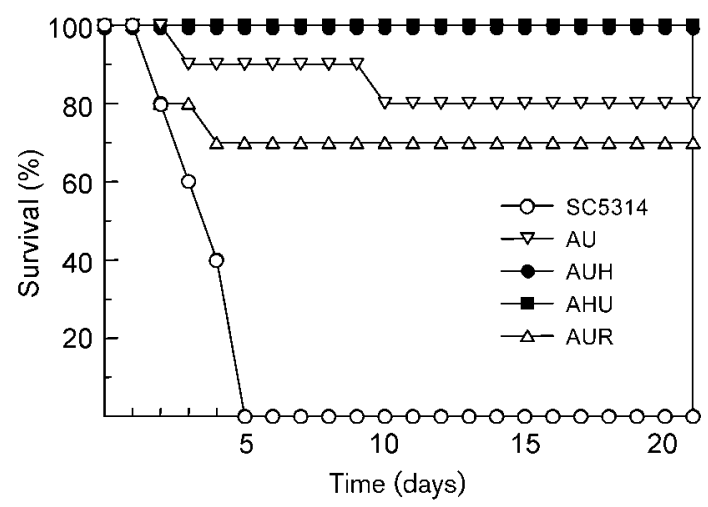

B
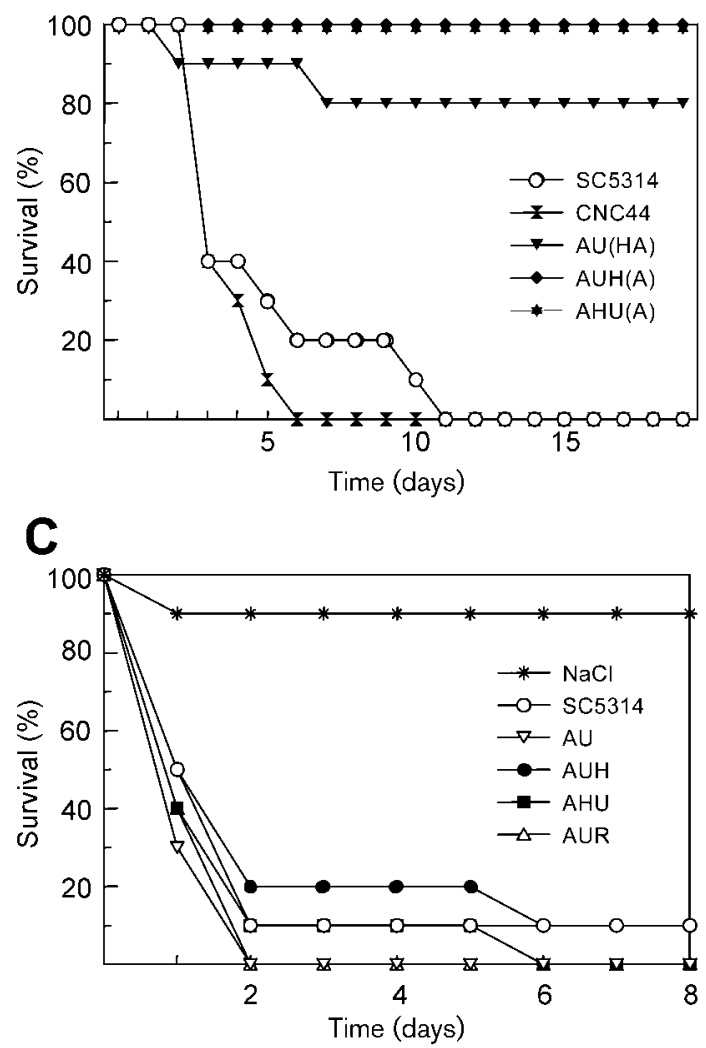

Fig. 6. Ade5,7p is involved in the pathogenicity of C. albicans. (A, B) C. albicans wild-type strain SC5314, the heterozygous mutant strains $A U$ and $A U(H A)$, ade5,7 null mutant strains $A U H, A H U$, $\mathrm{AUH}(\mathrm{A})$ and $\mathrm{AHU}(\mathrm{A})$, and $A D E 5,7$ revertant strain AUR were tested in a mouse model of systemic candidiasis. Survival of mice infected with $5 \times 10^{6}$ cells was monitored for (A) 21 days and (B) 19 days $(n=10)$. (C) SC5314, AU, AUH, AHU and AUR were tested in an alternative virulence model of embryonated hen eggs. Survival of embryonated hen eggs infected with $1 \times 10^{8}$ Candida cells was monitored for 8 days $(n=10)$. A $P$ value of $<0.05$ was considered to be significant (Peto et al., 1977).
21 days, only the null mutant strains showed a slightly reduced number of c.f.u.

\section{Construction and characterization of the prototrophic mutant strains}

The auxotrophies of the mutant strains may influence the phenotypes. Therefore, we characterized C. albicans CNC44 $\mathrm{Arg}^{-}$in addition to SC5314 to exclude that the $\mathrm{Arg}^{-}$auxotrophy of the null mutants influences the phenotypes. In addition, prototrophic heterozygous and homozygous mutant strains were constructed to rule out the potential of synthetic defects $\left(\mathrm{Ade}^{-}\right.$; $\mathrm{Arg}^{-}$) in the ade5,7 null mutants. A prototrophic revertant strain was not constructed because the identical phenotypes of two independently constructed ade5,7 null mutants had already shown that $A D E 5,7$ causes the changed phenotypes. The prototrophic mutants were characterized in an analogous way to the auxotrophic mutant strains. Insignificant differences were observed between the auxotrophic and prototropic strains. The reintegration of the HIS1 and ARG4 genes into the mutant strains did not change the phenotypes (data not shown) or the avirulence (Fig. 6A, B) significantly.

\section{DISCUSSION}

In this study, we demonstrate that Ade5,7p, the bifunctional enzyme of the de novo purine nucleotide biosynthetic pathway of the yeast C. albicans, interacts with the PtdIns 3-kinase Vps34p, and is involved in adenine synthesis, metal-ion detoxification, hyphal growth and virulence.

The physical interaction of Ade5,7p with Vps34p indicates a link between vacuolar transport and de novo nucleotide synthesis. This can be understood by the fact that both processes are regulated during periods of nutrient limitation. The recycling of cytoplasmic material in the vacuole results in the supply of material for the salvage pathway of purine synthesis, which is more active under nutrient limitation, and less active during de novo synthesis. The affected de novo synthesis may send a signal to start transport into the vacuole, possibly by physical interaction between Vps34p and Ade5,7p. Direct physical interaction between vacuolar transport proteins and enzymes of the de novo nucleotide synthesis has also been shown in $S$. cerevisiae. A physical interaction has been found between Ade5,7p and Apg12p, a protein of starvation-induced autophagocytosis, which is responsible for transport of cytoplasmic proteins into the vacuole (Ho et al., 2002).

Amino acids such as glutamine, glycine and aspartate are involved in de novo purine synthesis. Furthermore, general amino acid control (GAAC) is linked to purine synthesis, since the transcription factor Gcn $4 \mathrm{p}$, which regulates the transcription of more than 30 genes of GAAC, is required for maximal expression of one or several genes encoding purine biosynthesis proteins under conditions of purine 
limitation. Gcn $4 \mathrm{p}$ stimulates the expression of $A D E 5,7$ (Rolfes \& Hinnebusch, 1993), and, in addition, ADE5,7 expression is significantly induced by the GAAC system in a GCN4-dependent fashion in S. cerevisiae (Yin et al., 2004). Therefore, we hypothesize that Vps34p controls amino acid metabolism, in addition to regulating purine synthesis. This is supported by the finding of a physical interaction between a protein of the GAAC, i.e. the $C$. albicans $\mathrm{Gcn} 4 \mathrm{p}$-activator protein Gcn $1 \mathrm{p}$, and Vps34p in the two-hybrid system (unpublished data). In C. albicans, Gcn4p acts as a global regulator of both metabolic and morphogenetic response (e.g. hyphal growth) to amino acid starvation (Tripathi et al., 2002). Such a co-regulation of purine synthesis and hyphal growth under lowtemperature embedded conditions was shown here for Ade5,7p.

C. albicans ade5,7 null mutants were generated, and showed a defective growth on adenine-deficient medium, thus demonstrating a decisive role of Ade5,7p in the de novo purine biosynthesis pathway in $C$. albicans. The addition of extracellular adenine compensated this growth defect, and thus the salvage pathway is not affected. This effect is in agreement with data obtained for S. cerevisiae showing that Ade5,7p affects purine nucleotide biosynthesis (Giaever et al., 2002). The S. cerevisiae ade5,7 null mutant is viable, but exhibits a reduced fitness in rich medium (YPD). In addition, deletion of only one ADE5,7 allele in a diploid strain leads to reduced fitness in YPD medium (Deutschbauer et al., 2005). In contrast, the $C$. albicans ade5,7 null mutant strain was viable and showed normal growth in YPD medium. Therefore, the characterization of the ade5,7 null mutant strains is not biased by growth phenomena.

The vps34 and ade5,7 null mutant phenotypes could be caused indirectly by the absence of the corresponding genes. Nevertheless, in some cases, the genes could be involved directly in special cellular processes.

$\mathrm{Cu}^{2+}$ resistance is most likely to be a prerequisite for the survival of $C$. albicans in the digestive tract of the host, since the $\mathrm{Cu}^{2+}$ concentrations of about $10 \mu \mathrm{M}$ in the stomach and duodenum are relatively high (Underwood, 1977). The ade5,7 null mutants showed an increased sensitivity toward high concentrations of $\mathrm{Cu}^{2+}$ and $\mathrm{Ag}^{2+}$, which in S. cerevisiae are detoxified by the ATPase Ctrlp located at the plasma membrane (Riggle \& Kumamoto, 2000). The influence of targeting the plasma membrane (P)-ATPase by the vacuolar (V)-ATPase has been shown in S. cerevisiae (Perzov et al., 2000). We hypothesize that a defective Vps34p interacting with V-ATPase affects the distribution of P-ATPase in the ade5,7 null mutants, and thus leads to decreased $\mathrm{Cu}^{2+}$ and $\mathrm{Ag}^{2+}$ resistance (Eck et al., 2005; Perzov et al., 2000). The Ade5,7p protein possibly influences the P-ATPase, perhaps by interaction with the Vps34p-V-ATPase complex. In contrast to the vps34 null mutant (Poltermann et al., 2005), the ade5,7 null mutants did not show sensitivity to $\mathrm{Co}^{2+}, \mathrm{Mn}^{2+}, \mathrm{Ni}^{2+}$ or
$\mathrm{Zn}^{2+}$. In general, the ade5,7 mutants showed an increased sensitivity towards metal ions that are detoxified by PATPase, whereas the vps34 mutant showed sensitivity to metal ions that are detoxified by both V- and P-ATPase. In summary, both Ade5,7p and Vps34p play a role in metalion detoxification, as this is done by plasma membrane ATPase.

Hyphal growth in a matrix is regulated by the transcription factors Efglp and Czf1p. These two transcription factors act antagonistically, depending on the physical environment (Brown et al., 1999). Efglp promotes filamentous growth at $37{ }^{\circ} \mathrm{C}$ in liquid media, and represses hyphal development during growth within a matrix at low temperature, whereas Czflp antagonizes the repression mediated by Efglp and induces hyphal growth at low temperatures when cells are embedded within agar matrix (Giusani et al., 2002). Previously, we have reported that the C. albicans vps34 null mutant shows hyperfilamentation in an agar matrix (Kitanovic et al., 2005). In this study, we observed that the Vps34p-interacting protein Ade5,7p shows the opposite phenotype. Thus, we hypothesize that Ade5,7p and Vps34p may act antagonistically, and in a similar way to the transcription factors Efglp and Czflp. Vps34p regulates hyphal growth induced by the cAMP and MAP kinase pathways, and reduces hyphal differentiation in a matrix (Bruckmann et al., 2000; Kitanovic et al., 2005). However, the Ade5,7p protein activated hyphal growth in a matrix, and, thus, the Ade5,7p-Vps34p complex may affect the balance of hyphal growth under various conditions.

The ade5,7 null mutants showed avirulence in the mouse model, and this can be attributed to reduced kidney colonization. In the model of embryonated hen eggs, the ade5,7 null mutants showed high virulence. This may be attributed to different environmental conditions, e.g. the availability of adenine in the eggs, whereas in blood the concentration of adenine is too low for survival of the ade5,7 null mutant strains. The reduced kidney colonization is especially significant after 3 days of infection. This indicates that the low adenine concentration in blood prevents colonization at the beginning of the pathogenesis. After reaching the kidneys, the null mutant can grow almost equally as fast as the wild-type, and this results in a reduced difference between null mutant and wild-type strain regarding the kidney colonization at the end of virulence test. In addition, the reduced virulence of an ade2 null mutant in an immunosuppressed murine model of systemic candidiasis has confirmed the requirement of adenine de novo biosynthesis for pathogenesis of $C$. albicans (Donovan et al., 2001).

Deletion or change of locus of the URA3 gene may complicate the characterization of null mutants (Lay et al., 1998; Cheng et al., 2003). In this study, the URA3 gene was integrated at the same locus in the heterozygous and null mutant strains. The related phenotypes of the heterozygous mutant strain and of the wild-type strain did not indicate a URA3-position effect in the ade5,7 null mutant strains. 
Furthermore, the mutant phenotypes did not revert after addition of uridine to the medium (data not shown), and this confirms that the null mutant phenotypes do not result from a URA3-position effect.

In this study, we have shown that Ade5,7p, which is the $C$. albicans bifunctional enzyme of the de novo purine synthesis pathway, interacts with the vacuolar transport protein PtdIns 3-kinase Vps34p. The characterization of ade5,7 null mutants indicates that this interaction may influence cellular functions that are connected to detoxification, hyphal growth in a matrix, and virulence. In addition, the adenine auxotrophy of the ade5,7 null mutant strains seems to contribute to avirulence in the mouse model of systemic candidiasis.

\section{ACKNOWLEDGEMENTS}

We thank Federico Navarro-Garcia (Dept Microbiología II, Facultad de Farmacia, Universidad Complutense de Madrid, Madrid, Spain) and Aaron P. Mitchell (Department of Microbiology, Columbia University, New York, NY, USA) for providing C. albicans strains CNC44 and BWP17. We thank U. Stöckel and B. Weber for technical assistance.

\section{REFERENCES}

Arnaud, M. B., Costanzo, M. C., Skrzypek, G., Lane, C., Miyasato, S. R. \& Sherlock, G. (2005). The Candida Genome Database (CGD), a community resource for Candida albicans gene and protein information. Nucleic Acids Res 33, D358-D363.

Arndt, K. T., Styles, C. \& Fink, G. R. (1987). Multiple global regulators control HIS4 transcription in yeast. Science 237, 874-880.

Brown, D. H., Jr, Giusani, A. D., Chen, X. \& Kumamoto, C. A. (1999). Filamentous growth of Candida albicans in response to physical environmental cues and its regulation by the unique $C Z F 1$ gene. Mol Microbiol 34, 651-662.

Bruckmann, A., Künkel, W., Härtl, A., Wetzker, R. \& Eck, R. (2000). A phosphatidylinositol 3-kinase of Candida albicans influences adhesion, filamentous growth, and virulence. Microbiology 146, 2755-2764.

Cheng, S., Nguyen, M. H., Zhang, Z., Jia, H., Handfield, M. \& Clancy, C. J. (2003). Evaluation of the roles of four Candida albicans genes in virulence by using gene disruption strains that express URA3 from the native locus. Infect Immun 71, 6101-6103.

Cutler, J. E. (1991). Putative virulence factors of Candida albicans. Annu Rev Microbiol 45, 187-218.

D'Enfert, C., Goyard, S., Rodriguez-Arnaveilhe, S., Frangeul, L., Jones, L., Tekaia, F., Bader, O., Albrecht, A., Castillo, L. \& other authors (2005). CandidaDB: a genome database for Candida albicans pathogenomics. Nucleic Acids Res 33, D353-D357.

Daignan-Fornier, B. \& Fink, G. R. (1992). Coregulation of purine and histidine biosynthesis by the transcriptional activators BAS1 and BAS2. Proc Natl Acad Sci U S A 89, 6746-6750.

Davis, D., Edwards, J. E., Jr, Mitchell, A. P. \& Ibrahim, A. S. (2000). Candida albicans RIM101 pH response pathway is required for hostpathogen interactions. Infect Immun 68, 5953-5959.

Deutschbauer, A. M., Jaramillo, D. F., Proctor, M., Kumm, J., Hillenmeyer, M. E., Davis, R. W., Nislow, C. \& Giaever, G. (2005). Mechanisms of haploinsufficiency revealed by genome-wide profiling in yeast. Genetics 169, 1915-1925.
Donovan, M., Schumuke, J. J., Fonzi, W. A., Bonar, S. L., GheeslingMullis, K., Jacob, G. S., Davisson, V. J. \& Dotson, S. B. (2001). Virulence of a phosphoribosylaminoimidazole carboxylase-deficient Candida albicans strain in an immunosuppressed murine model of systemic candidiasis. Infect Immun 69, 2542-2548.

Eck, R., Bruckmann, A., Wetzker, R. \& Künkel, W. (2000). A phosphatidylinositol 3-kinase of Candida albicans: molecular cloning and characterization. Yeast 16, 933-944.

Eck, R., Nguyen, M., Günther, J., Künkel, W. \& Zipfel, P. F. (2005). The phosphatidylinositol 3-kinase Vps34p of the human pathogenic yeast Candida albicans is a multifunctional protein that interacts with the putative vacuolar $\mathrm{H}^{+}$-ATPase subunit Vma7p. Int J Med Microbiol 295, 57-66.

Ernst, J. F. (2000). Transcription factors in Candida albicans - environmental control of morphogenesis. Microbiology 146, 1763-1774.

Fonzi, W. A. \& Irwin, M. Y. (1993). Isogenic strain construction and gene mapping in Candida albicans. Genetics 134, 717-728.

Giaever, G., Chu, A. M., Ni, L., Connelly, C., Riles, L., Veronneau, S., Dow, S., Lucau-Danila, A., Anderson, K. \& other authors (2002). Functional profiling of the Saccharomyces cerevisiae genome. Nature 418, 387-391.

Giusani, A. D., Vinces, M. \& Kumamoto, C. A. (2002). Invasive filamentous growth of Candida albicans is promoted by Czflpdependent relief of Efglp-mediated repression. Genetics 160, 1749-1753.

Gola, S., Martin, R., Walther, A., Dunkler, A. \& Wendland, J. (2003). New modules for PCR-based gene targeting in Candida albicans: rapid and efficient gene targeting using $100 \mathrm{bp}$ of flanking homology region. Yeast 20, 1339-1347.

Härtl, A., Hillesheim, H. G., Künkel, W. \& Schrinner, E. J. (1995). The Candida infected hen's egg. An alternative test system for systemic anticandida activity. Arzneimittelforschung 45, 926-928.

Härtl, A., Möllmann, U., Schrinner, E. \& Stelzner, A. (1997). Pseudomonas aeruginosa infection in embryonated hen's eggs. Arzneimittelforschung 47, 1061-1064.

Henikoff, S. (1987). Multifunctional polypeptides for purine de novo synthesis. Bioessays 6, 8-13.

Ho, Y., Gruhler, A., Heilbut, A., Bader, G. D., Moore, L., Adams, S. L., Millar, A., Taylor, P., Bennett, K. \& other authors (2002). Systematic identification of protein complexes in Saccharomyces cerevisiae by mass spectrometry. Nature 415, 180-183.

Jones, E. W. \& Fink, G. R. (1982). In The Molecular Biology of the Yeast Saccharomyces - Metabolism and Gene Expression, pp. 181-299. Edited by J. N. Strathern, E. W. Jones \& J. R. Broach. Cold Spring Harbor, NY: Cold Spring Harbor Laboratory.

Kitanovic, A., Nguyen, M., Vogel, G., Hartmann, A., Günther, J., Würzner, R., Künkel, W., Wölfl, S. \& Eck, R. (2005). Phosphatidylinositol 3-kinase VPS34 of Candida albicans is involved in filamentous growth, Saps secretion, and intracellular detoxification. FEMS Yeast Res 5, 431-439.

Köhler, J. R. \& Fink, G. R. (1996). Candida albicans strains heterozygous and homozygous for mutations in mitogen-activated protein kinase signaling components have defects in hyphal development. Proc Natl Acad Sci U S A 93, 13223-13228.

Kranz, A., Kinner, A. \& Kölling, R. (2001). A family of small coiledcoil-forming proteins functioning at the late endosome in yeast. Mol Biol Cell 12, 711-723.

Lay, J., Henry, L. K., Clifford, J., Koltin, Y., Bulawa, C. E. \& Becker, J. M. (1998). Altered expression of selectable marker URA3 in genedisrupted Candida albicans strains complicates interpretation of virulence studies. Infect Immun 66, 5301-5306. 
Lee, K. L., Buckley, H. R. \& Campbell, C. C. (1975). An amino acid liquid synthetic medium for the development of mycelial and yeast forms of Candida albicans. Sabouraudia 13, 148-153.

Liu, T. T., Lee, R. E. B., Barker, K. S., Lee, R. E., Wei, L., Homayouni, R. \& Rogers, P. D. (2005). Genome-wide expression profiling of the response to azole, polyene, echinocandin, and pyrimidine antifungal agents in Candida albicans. Antimicrob Agents Chemother 49, 2226-2236.

Madani, N. D., Malloy, P. J., Rodriguez-Pombo, P., Krishnan, A. V. \& Feldman, D. (1994). Candida albicans estrogen-binding protein gene encodes an oxidoreductase that is inhibited by estradiol. Proc Natl Acad Sci U S A 91, 922-926.

Negredo, A., Monteoliva, L., Gil, C., Pla, J. \& Nombela, C. (1997). Cloning, analysis and one-step disruption of the ARG5,6 gene of Candida albicans. Microbiology 143, 297-302.

Odds, F. C. (1994). Pathogenesis of Candida infections. J Am Acad Dermatol 31, S2-S5.

Perzov, N., Nelson, H. \& Nelson, N. (2000). Altered distribution of the yeast plasma membrane $\mathrm{H}^{+}$-ATPase as a feature of vacuolar $\mathrm{H}^{+}$-ATPase null mutants. J Biol Chem 275, 40088-40095.

Peto, R., Pike, M. C., Armitage, P., Breslow, N. E., Cox, D. R. V., Howard, S., Mantel, N., McPherson, K., Peto, J. \& Smith, P. G. (1977). Design and analysis of randomized clinical trials requiring prolonged observation of each patient. II. Analysis and examples. Br J Cancer 35, $1-39$.

Poltermann, S., Nguyen, M., Günther, J., Wendland, J., Härtl, A., Künkel, W., Zipfel, P. F. \& Eck, R. (2005). The putative vacuolar
ATPase subunit Vma7p of Candida albicans is involved in vacuole acidification, hyphal development and virulence. Microbiology 151, 1645-1655.

Riggle, P. J. \& Kumamoto, C. A. (2000). Role of the Candida albicans P1-type ATPase in resistance to copper and silver ion toxicity. $J$ Bacteriol 182, 4899-4905.

Rolfes, R. J. \& Hinnebusch, A. G. (1993). Translation of the yeast transcriptional activator GCN4 is stimulated by purine limitation: implications for activation of the protein kinase GCN2. Mol Cell Biol 13, 5099-5111.

Tripathi, G., Wiltshire, C., Macaskill, S., Tournu, H., Budge, S. \& Brown, A. J. P. (2002). Gcn 4 co-ordinates morphogenetic and metabolic responses to amino acid starvation in Candida albicans. EMBO J 21, 5448-5456.

Underwood, E. J. (1977). Trace Elements in Human and Animal Nutrition. London: Academic Press.

Wilson, R. B., Davis, D. \& Mitchell, A. P. (1999). Rapid hypothesis testing with Candida albicans through gene disruption with short homology regions. J Bacteriol 181, 1868-1874.

Yin, Z., Stead, D., Selway, L., Walker, J., Riba-Garcia, I., Mclnerney, T., Gaskell, S., Oliver, S. G., Cash, P. \& Brown, A. J. P. (2004). Proteomic response to amino acid starvation in Candida albicans and Saccharomyces cerevisiae. Proteomics 4, 2425-2436.

Zalkin, H. Z. \& Dixon, J. E. (1992). De novo purine nucleotide biosynthesis. Prog Nucleic Acid Res Mol Biol 42, 259-287.

Edited by: D. Sanglard 